\title{
高压スライムポンプの研究
}

河村 左武 郎**

\section{Study on High Pressure Slime Pumps}

Saburo KAWAMURA

\section{1. まえがき}

鉱山における選鉱工場の操業系統ではスライム輸送ポ ンプは不可欠の存在であるが、現在使用されているポン プを大別すると回転ポンプと往復動ポンプである。

回転ポンプは主として選鉱工場内の繰り返し系統で大 体 $50 \mathrm{~m}$ 以下の低圧でしかす比較的濃度の低い輸送に使用 され、それ以上の高揚程や高濃度のスライム輸送になる と回転ポンプの使用は困難で往復動ポンプに頼らなけれ ばならない。

選鉱工場内で使われている往復動ポンプで最屯ポピュ ラーなのはダイヤフラムポンプであり、このポンプは消 耗部品あ少なく操業上のトラブルあ比較的少ないが、そ の構造上、使用可能圧力が $15 \mathrm{~kg} / \mathrm{cm}^{2}$ 位までが適当であ り、それ以上の高圧になると、いろいろの問題が生ずる ので、2段、3段の中継輸送をしなければならない。

中継輸送は設備費や人件費が畒むのみならず、操業上 にむいろいろなトラブルが、つきまとうので高圧スライ ムポンプの必要性が業界の一致した要望である。

最近特に各鉱山共サンドスライムの坑内充填方式が採 用される事になり、なお一層との要望が大きくクローズ アップされている。

\section{2. 往復動高圧スライムポンプの現状}

現在使用されている高压スライムポンプとしては、現 在各鉱山で使用されているポンプ以外に見るべきものは なく、このポンプは構造あ割合簡単で、しかむ70〜80 $\mathrm{kg} / \mathrm{cm}^{2}$ 以上の高压にむ充分耐え得るので、専ら推積場 への廃滓の輸送や、サンドスライム充填のための高圧輸 送に使用されているが、このポンプの大きな欠点は、シ リンダーに直接スライムが出入する構造であるために、 シリンダーライナー、ピストン、ピストンロッド、グラ ンドパッキングの 摩損が甚しく、特に高圧になるに従 い、加速度的にこれらの摩耗が多くなり、消耗部品費の

\footnotetext{
受 理 昭和 38 年 10 月 10 日

* 第30回例会研究発表 (昭和38年 5 月11日)

** 三菱金属鉣業株式会社 生野製作所副長
}

増大と部品取替労務費の増加のために高価な翰送費とな るので、そつ耐摩耗対策には従来共、あらゆる研究が重 ねられて来た。

例えばシリンダーライナー内面に高周波焼入れを施し て、その硬度を上げる方法、硬質クロームメッキを施し て耐摩耗性を增す方法等、ある程度の効果はあげている が、いづれも決定的解決策にならず、依然として高压ス ライムポンプの問題は、鉱山業界の一つの共通問題とし て、その解決が要望されて扣り、鉱業協会主催の現場担 当者会議には、毎年これ等の問題が提出されている。

\section{3. 新型スライムポンプ試作までの経緯}

以上の様に在来の高圧スライムポンプに対する耐摩耗 対策の研究にもかかわらず、問題が依然として解決され ないので、何か、これに代るべき高圧ポンプを作る検討 をはじめた。

先ず考え方としては、バルブ関係は、いずれにしても サンドスライムを直接通過させないわけにはいかないの で、この問題は後日にゆずる事として、シリンダーに直 接スライムを入れなければ摩耗が生じないので、その事 を中心に検討を進めた。

ダイヤフラムポンプは、シリンダー側に油を使用して いるために、シリンダーやプランジャーに殆んど摩耗が 生じないが、スライムとの隔壁にゴムのダイヤフラムを 使用しているために、このゴム板の強度や寿命に問題が あつて高压には使用できないので、何とかして、このネ ックであるゴム板を使わない構造を中心に考えた。

皆加ら水之油は相性の合わない事の代名詞に使わ机て 来たあのであるが、その主な原因の一つが比重差にある ので、その比重差を利用すればよい事に気がついた。

ダイヤフラムポンプのケーシングは、油と水を縦に分 けているために、そ0境界にゴムのフラムを置かなけれ ばならないのであるから、これを上下に分けて、比重差 を利用すればこのダイヤフラムを設けなくとあ油と水を 混合しない事になるので、シリンダーとバルブボックス との間にオイルチャンバーを設けて、その上部に油、下 部に水を入れればよいという結論に達した。 
第 1 表 某鉱山における在来のスライムポンプ $\left(41 / 22^{\prime \prime} \times 10^{\prime \prime}\right.$ 型 $)$ の消耗部品実績の一例

\begin{tabular}{|c|c|c|c|c|c|c|}
\hline 項 目 & 数量 & 単 価 & 金 額 & $\begin{array}{c}\text { 奏送泥量 } \\
1 \text { 時間 } \\
\text { 当 り }\end{array}$ & $\begin{array}{l}\text { 送泥量 } \\
1 \mathrm{~m}^{3} \\
\text { 当り }\end{array}$ & $\begin{array}{c}\text { 送泥乾量 } \\
1 \text { ton } \\
\text { 当 } b\end{array}$ \\
\hline (1) Oリング & 6 & $\begin{array}{r}\text { 四 } \\
250\end{array}$ & $\begin{array}{r}\text { 円 } \\
1,500\end{array}$ & $\begin{array}{l}\text { 円 } \\
1.65\end{array}$ & $\begin{array}{l}\text { 円 } \\
0.05\end{array}$ & $\begin{array}{l}\text { 円 } \\
0.09\end{array}$ \\
\hline (2) ピストンラバー & 32 & 1,100 & 35,200 & 78.69 & 1.19 & 2.21 \\
\hline (3) ピストンロッド & 7 & 6,800 & 47,600 & 52.33 & 1.62 & 2.97 \\
\hline (4) ピストンボデー & 14 & 4,200 & 58,800 & 64.64 & 1.99 & 3.70 \\
\hline (5) シリンダーライナー & 11 & 17,000 & 187,000 & 205.56 & 6.34 & 11.75 \\
\hline (6) Vパッキング & 105 & 120 & 12,600 & 13.85 & 0.43 & 0.79 \\
\hline (7) 凸型パッキング & 3 & 450 & 1,350 & 1.48 & 0.05 & 0.07 \\
\hline (8) 凹型パッキング & 1 & 480 & 480 & 0.53 & 0.02 & 0.03 \\
\hline (9) ライナーパッキング & 1 & 650 & 650 & 0.71 & 0.02 & 0.04 \\
\hline $\begin{array}{l}\text { (10) オイルストップヘッド } \\
\text { オイパーパッキング }\end{array}$ & 1 & 200 & 200 & 0.22 & 0.01 & 0.01 \\
\hline (11) ピストンロッドリング & 4 & 550 & 2,200 & 2.42 & 0.07 & 0.14 \\
\hline (12) シリンダーカバーパッキング & 3 & 650 & 1,950 & 2.14 & 0.07 & 0.12 \\
\hline (13) バルブラバー & 185 & 360 & 66,600 & 73.21 & 2.26 & 4.19 \\
\hline (14) バルブガイド & 5 & 2,200 & 11,000 & 12.09 & 0.37 & 0.69 \\
\hline (15) 同上 (再生産) & 40 & 520 & 20,800 & 22.87 & 0.70 & 1.31 \\
\hline (16) バルブシート & 2 & 3,600 & 7,200 & 7.91 & 0.24 & 0.45 \\
\hline (17) 同上 (再生産) & 30 & 530 & 15,900 & 17.48 & 0.54 & 1.00 \\
\hline (18) バルブボデー & 7 & 2,300 & 16,100 & 17.70 & 0.55 & 1.01 \\
\hline (19) 同上 (再生産) & 4 & 510 & 2,040 & 2.24 & 0.07 & 0.13 \\
\hline (20) サクションバルブスプリング & 1 & 220 & 220 & 0.24 & 0.01 & 0.01 \\
\hline (21) デリベリーバルブスプリング & 1 & 180 & 180 & 0.20 & 0.01 & 0.01 \\
\hline (22) 其の他 & 1 & 180 & $\begin{array}{r}180 \\
489,750\end{array}$ & 0.20 & 0.01 & 0.01 \\
\hline
\end{tabular}

使用ポンプ仕様

$$
\begin{aligned}
& \text { シリンダー径メストロー } \\
& \text { ク(时) } \quad 41 / 2 " \times 10^{\prime \prime} \\
& \text { モータ一馬力 (IP) } 100 \\
& \text { ポンプ回転数 }(\mathrm{r} / \mathrm{m}) \quad 56
\end{aligned}
$$

48 54

吐出容量 $\left(\mathrm{m}^{3} / \mathrm{hr}\right)$

32.4

サンドスライム節分表

\begin{tabular}{c|c|c}
\hline メッシュ & +48 & +65 \\
\hline$\%$ & 5.15 & 7.84 \\
\hline+100 & +150 & +200 \\
\hline 24.75 & 25.00 & 15.69 \\
\hline+270 & +325 & -325 \\
\hline 7.60 & 3.86 & 10.29 \\
\hline
\end{tabular}

運転期間 5 ケ月

実送泥時間 二910時間

(182時間/月 7.3時間/日)

送泥濃度 35 45\%

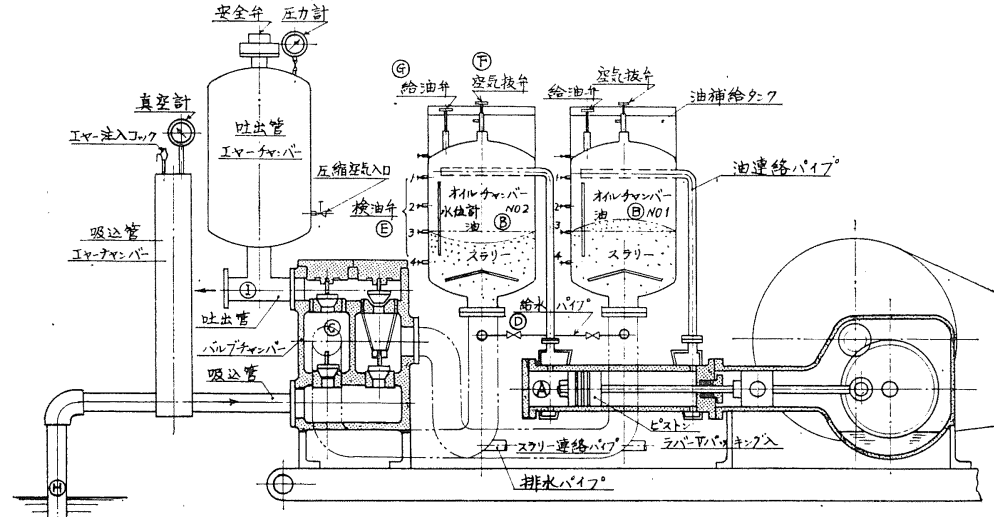

第1図 新型スライムポンプ説明図
ッキング等は油中の完全潤滑 の状態で使用されるので、そ の寿命は半永久的であるむの と確信した。

\section{4. 構造概要及び 使用方法}

\section{構造概要 (第 1 図)}

シリンダー(A)とバルブボッ クス(C)との間に竪型のオイル チャンバー(B)を設置し、その 上部に油、下部に水を入れて ある。

チャンバー(B)の中の油と水
しかし、如何に油と水でも、激しく摇動を与えれば、 気泡状態になつて混入を生ずる事になるので、その構造 や形をいろいろ研究した結果一応の結論が得られたの で、第1図の様な試作ポンプを設計製作した。

即ち、シリンダーは油だけしか入らないので、シリン ダーライナー、ピストン、ピストンロッド、グランドパ
は、その比重差により上下に分かれポンプを運転してむ シリンダー(A)には、絶対に水（またはスライム）が浸入 しない構造になつている。

従つて、シリンダー、ピストン関係部品の摩耗は殆ん ご生じない。

使用方法 
給水パイプ(D)より清水（スライムでも可）を注入し、 検出コック $(\mathrm{E})$ より水が出たら、下部（バルブボックスを 含む）に満水した事になるので注水を止める。

次にタンク $(\mathrm{B})$ の上部の空気抜弁 $(\mathrm{F})$ を開き、給油弁 $(\mathrm{G})$ 上 り油を入れると、タンク内の空気は油に排除されタンク 上部まで油が充満する。

油が充満したら $(\mathrm{G}) 、(\mathrm{~F})$ 在閉じる。

ポンプを起動すれば、ピストンの往復動に従つてタン ク(B)の油はシリンダー(A)に出入りし、そのためにタンク (B)の油とスライムの境界面が上下運動を生じ、サクショ ンパイプ $(\mathrm{H})$ より水を吸入し、バルブボックスを経てデリ ベリーパイプ(I)より吐出する。

\section{5. 試作 1 号機の工場並に現場試験実績}

試作 1 号機は第 1 図の様に、単シリンダーで、その仕 様は次の通りである。

$$
\begin{array}{lll}
\text { シリンダー径メストローク } & 170 \mathrm{~m} / \mathrm{m} \times 350 \mathrm{~m} / \mathrm{m} \\
\text { 最高压力 } & 40 \mathrm{~kg} / \mathrm{cm}^{2} \\
\text { 回 転 数 } & 60 、 20 \\
\text { 揚 水 量 } & 800 \mathrm{l} / \mathrm{min} 、 300 \mathrm{l} / \mathrm{min} \\
\text { 使用電動機 } & 75 \mathrm{P} 、 40 \mathrm{P}
\end{array}
$$

\section{工場試験成績}

第 2 表 参照

上記の通り工場試運転において一応の成功を収めたの で、尾去沢、生野両鉱業所においてそれぞれ、現場試験 を行なつた。

\section{尾去沢における試験}

使用箇所は選鉱工場より坑内充填用のサンドスライム
第 2 表 ポンブ試験表

昭和37年 8 月 30 日

仕様 ンリンダー径 $170 \mathrm{~m} / \mathrm{m}$ 中、シリンダー数 1 、行程 $350 \mathrm{~m} / \mathrm{m}$ 回転数 $52 \mathrm{R} / \mathrm{M}$ 、全俚力 $20 \mathrm{~kg} / \mathrm{cm}^{2}$ 揚液量 $693 \mathrm{l} / \mathrm{min}$

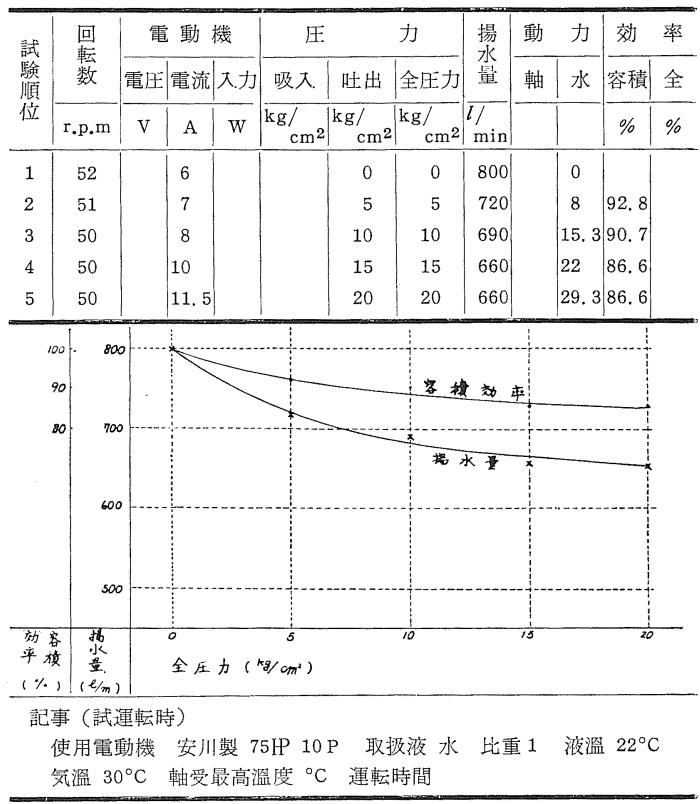

を坑内に送るポンプとして使用した。

従つて、選鉱の廃滓をサイクロン分級機にかけそのア ンダーを選泥した。

\begin{tabular}{|c|c|c|c|c|c|c|c|c|c|c|c|c|}
\hline & 使 & 用 & 期 & 間 & $\begin{array}{c}36 / 9 / 8 \\
\sim 9 / 16 \\
\end{array}$ & $9 / 19$ & $\begin{array}{l}9 / 20 \\
\sim 9 / 26\end{array}$ & $9 / 28$ & $\begin{array}{c}10 / 4 \sim \\
10 / 14\end{array}$ & \multirow[b]{2}{*}{ 小 } & $\begin{array}{c}10 / 17 \\
\sim 11 / 16 \\
\end{array}$ & \multirow[b]{2}{*}{ 計 } \\
\hline & 使 & 用 & 条 & 件 & $\begin{array}{l}\text { スラリー } \\
\text { 連絡パイ } \\
\text { ブをV型 } \\
\text { に改め }\end{array}$ & 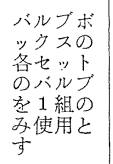 & 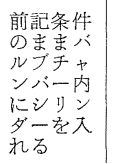 & 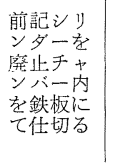 & 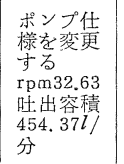 & & & \\
\hline \multicolumn{5}{|c|}{ 運 転 時 間 } & 30.05 & 4.55 & 51.43 & 15.40 & 140.55 & 243.18 & 275.00 & 518.18 \\
\hline \multicolumn{5}{|c|}{ 試験運転時間 } & 2.00 & 3.00 & 7.10 & 0.30 & 18.55 & 31.35 & - & 31.35 \\
\hline \multicolumn{5}{|c|}{ サンドスライム充垻揚泥時間 } & 25.55 & 1.15 & 40.50 & 14.10 & 111.20 & 193.35 & 260.35 & 454.10 \\
\hline \multicolumn{5}{|c|}{ 送泥パイプ洗滌時間 } & 2.10 & 0.40 & 3.43 & 1.00 & 10.40 & 18.13 & 14.25 & 32.38 \\
\hline \multicolumn{4}{|c|}{ サンドスライム掦泥量 } & $\mathrm{m}^{3}$ & 404.6 & 20.2 & 653.0 & 229.5 & $1,922.5$ & $3,229.8$ & $4,729.8$ & $7,959.6$ \\
\hline \multicolumn{4}{|c|}{ サンドスライム含鉱量 } & $\mathrm{T}$ & $448 . \overline{8}$ & 21.9 & $705 . \overline{8}$ & $248 . \overline{6}$ & $2,089.7$ & $3,514 . \overline{8}$ & $5,199.0$ & $8,713 . \overline{8}$ \\
\hline \multicolumn{4}{|c|}{ サンドスライム揚泥量 } & $\mathrm{m}^{3} /$ 分 & 0.2601 & $0.270^{-}$ & 0.2665 & $0.2700^{-}$ & 0.2877 & 0.2781 & 0.3025 & 0.2920 \\
\hline \multicolumn{5}{|c|}{ サンドスライム揚泥含鉱量 $\mathrm{T} /$ 分 } & 0.2886 & 0.292 & $0.28 \overline{8}$ & $0.292 \overline{4}$ & 0.3128 & 0.3027 & 0.3325 & $0.319 \overline{8}$ \\
\hline \multicolumn{5}{|c|}{ 每時間当送鉱量 $\quad \mathrm{T} /$ 時 } & $17,31 \overline{6}$ & 17,520 & 17,280 & $17,54 \overline{4}$ & 18,768 & 18,162 & 19,950 & - \\
\hline \multicolumn{5}{|c|}{ 揚 泥 压力 $\mathrm{kg} / \mathrm{cm}^{2}$} & 13.5 & 20.0 & 9.6 & 15.5 & 11.7 & 11.82 & 12.15 & - \\
\hline \multicolumn{5}{|c|}{ 揚 泥 濃 度 } & 65.92 & 65.0 & 64.7 & 65.0 & 65.2 & 65.16 & 65.61 & - \\
\hline
\end{tabular}

穊分サイズ

$$
\begin{array}{ll}
\text { +65メッシュ以上が } & 22 \sim 27 \% \\
-325 \times ッ シ ュ & 5 \sim 6 \%
\end{array}
$$

濃 度 $66 \%$

第 3表 新型スライムポンプ運軽実績 


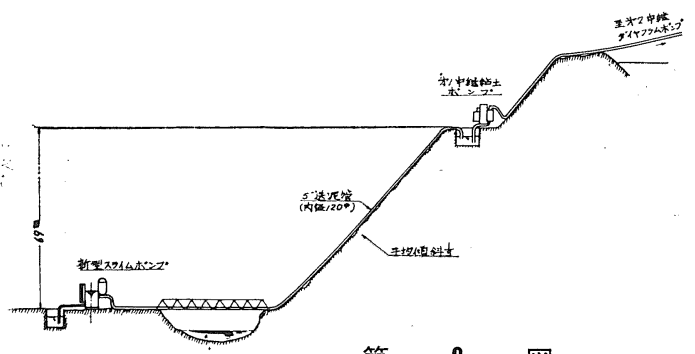

第 2 図

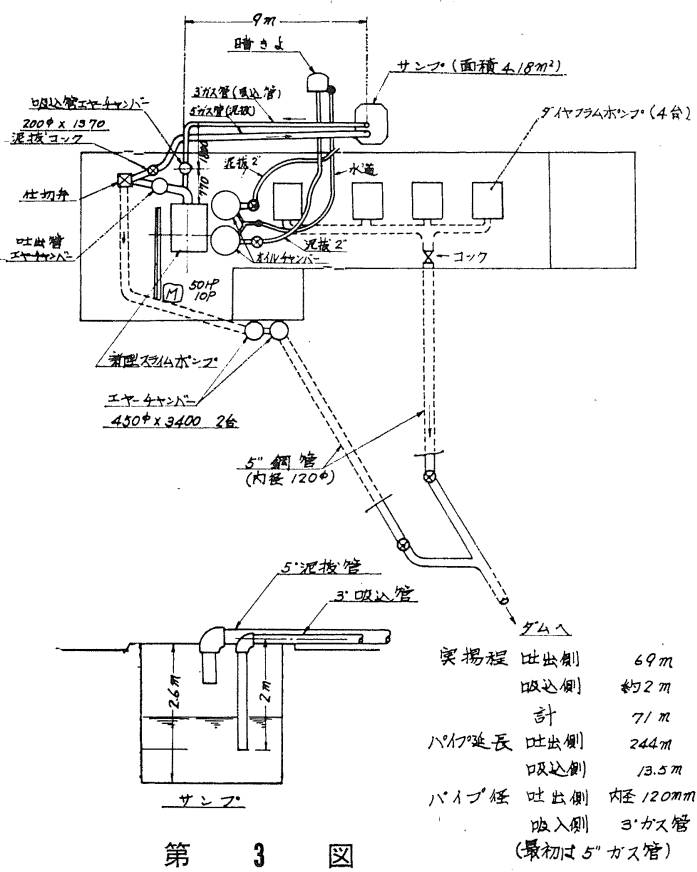

粒度分布

\begin{tabular}{l|c|c|c|c|c|c|c}
\hline 粒度 $(\mathrm{mesh})$ & +65 & +100 & +150 & +200 & +325 & -325 & 計 \\
\hline 分布率 $(w t \%)$ & 0.04 & 0.08 & 0.64 & 2.99 & 6.84 & 89.41 & 100
\end{tabular}

給鉱方法は吸揚方式でなく、サイクロンのアンダーを そのままホッパーに落して、サクションパイプに流入さ せる方法をとつたので、サクションパイプにはサンドス ライムと空気とが混合吸入される状態であつた。

成績は第 3 表及び第 4 図の通りである。

結論としては、後に述べる様に今後製作するポンプに 対する改良の諸条件が発見されたが、518 時間運転の結 果 $30 \mathrm{~kg} / \mathrm{cm}^{2}$ までの圧力で 容積効率も $90 \%$ 以上確保で き、良好な成績を収めた。

\section{生野鉱業所に於ける試験}

目的

尾去沢で 2 ケにわたつて試験を行なつたが、操業の 都合上、断続運転のみであつて、長時間の連続運転を行

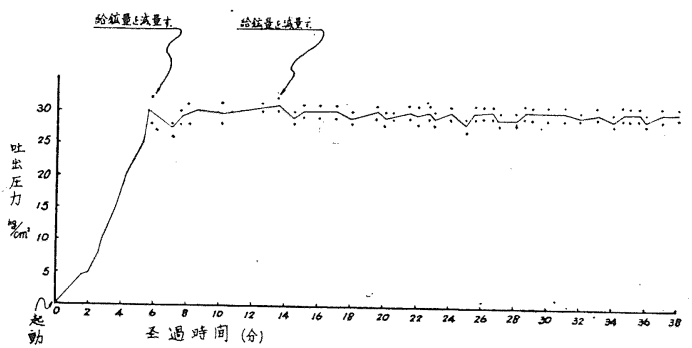

第 4 図 吐出圧力 $30 \mathrm{~kg} / \mathrm{cm}^{2}$ 送泥に打殀压力 計指示

条件 1 . 本吐出圧力は使用 $30 \mathrm{~kg} / \mathrm{cm}^{2}$ 在来 スラムポンプ $4 \frac{1}{2} / 2^{\prime \prime} \times 10^{\prime \prime} \times 70 \mathrm{~kg} /$ $\mathrm{cm}^{2}$ における送泥と同一に維持し 吐出量を比較するあのである。

2. 送泥条件、パイプ距離は在来スラ イムポンプ $41 / 2 " 1 \times 10^{\prime \prime} \times 70 \mathrm{~kg} / \mathrm{cm}^{2}$ における条件と同一である。

3. 同一送泥条件における送泥量の同 一圧力における比較のためである。

4. 圧力計指示の変動は在来スライム ポンプ同一条件におけるときより 上下動が多い。

5. 圧力計変動によるプロット上下は その時間における高低を示す。

なう事と、マイナスバッグの吸入状態における試験が主 目的であつた。

配置状沉は第 2 図、第 3 図参照

第 1 回試験として $60 \mathrm{r} / \mathrm{m}$ で運転を行なつた結果、激し いハンチングによる振動と異状音を発し、油の温度む上 昇し、運転継続不能であつた。

この原因は後述の検討の項に詳述寸るので、ここでは 省略するが結論は、サクション抵抗の過大であつた。

次に回転を $25 \mathrm{r} / \mathrm{m}$ にして運転し、かつ油連結パイプ の改造等直ちには困難なので、サクションパイプにエヤ 一チャンバーをつけてサクション抵抗を軽減して運転し た。

その結果、油とスライムの混濁状態は満 5 日間（116 時間) 連続運転を行なつたが、大体確信の持てるデータ 一を得る事ができた。

即ち、116 時間運転し、その間 4 回オイルチャンバー から試料を取つたが、油中に混入しているスライムの量 は殆んご変化なく、混入量む境界面だけで量も少なく、 粒度む小さいものだけである事が执かた。

以上の結果から設計を一部改良すればスライム輸送用 として、在来のスライムポンプよりあ遥汃にランニング コストにおいて有利に使用できる事が確認された。

\section{社外 $\mathbf{N}$ 鉱山における試験}

生野において実験したマイナスバッグの場合のサクシ ヨン抵抗増大によるハンチング現象を解決するため、シ 
第4表 新型スライムポンプ揚水量

\begin{tabular}{|c|c|c|c|c|c|c|c|c|}
\hline 測 定時間 & $\left|\begin{array}{|}\text { フィー } \\
\text { ド濃度 }\end{array}\right|$ & $\begin{array}{ll}\text { ピット } \\
\text { 濃度 }\end{array}$ & $\begin{array}{l}\text { ゲージ } \\
\text { 压力 }\end{array}$ & $\begin{array}{l}\text { 揚水量 } \\
\mathrm{m}^{3} / \mathrm{min}\end{array}$ & $\mid \begin{array}{r}\text { ピット内 } \\
0.5 \mathrm{~m} \\
\text { 吸揚時間 }\end{array}$ & 効率 & $\begin{array}{l}\text { アン } \\
\text { ペア }\end{array}$ & $\begin{array}{l}\text { エヤー } \\
\text { 拻 き }\end{array}$ \\
\hline $3 \mathrm{D} \cdot 18 \mathrm{~h}$ & $\%$ & $\begin{array}{r}\% \\
34.5\end{array}$ & $\underset{25}{\mathrm{~kg} / \mathrm{cm}^{2}}$ & 0.6458 & $\begin{array}{cc}\text { 分 } & \text { 秒 } \\
4 & 48\end{array}$ & $\begin{array}{r}\% \\
82.0\end{array}$ & $7.5^{\mathrm{A}}$ & \\
\hline " $19 \mathrm{~h}$ & & 36.9 & 25 & 0.6619 & $4 \quad 41$ & 84.4 & 7.7 & 18 時45分 \\
\hline $20 \mathrm{~h}$ & & 37.8 & 26 & 0.6562 & $4 \quad 43$ & 83.7 & 7.6 & \\
\hline $21 \mathrm{~h}$ & & 36.2 & 25 & 0.6690 & 438 & 85.2 & 7.7 & \\
\hline $22 \mathrm{~h}$ & & 36.2 & 26 & 0.6562 & 443 & 83.7 & 7.8 & \\
\hline 平均 & & 36.32 & 25.4 & 0.65728 & $4 \quad 42$ & $\fallingdotseq 84$ & 7.66 & \\
\hline $6 \mathrm{D} 9 \mathrm{~h} 30 \mathrm{~m}$ & 6.1 & 7.1 & & 0.6485 & & & & \\
\hline " $10 \cdot 30$ & 5.7 & 7.2 & & 0.6432 & & & & \\
\hline " $11 \cdot 30$ & 36.8 & 43.4 & & 0.6499 & & & & 11時30分 \\
\hline " $12 \cdot 30$ & 8.4 & 16.9 & & 0.6526 & & & & \\
\hline " $13 \cdot 30$ & 9.8 & 11.6 & & 0.6596 & & & & 13時30分 \\
\hline " $14 \cdot 30$ & 8.4 & 10.4 & & 0.6624 & & & & \\
\hline " $15 \cdot 30$ & 5.8 & 8.4 & & 0.6554 & & & & \\
\hline 平 & 11.57 & 15.0 & & 0.6530 & & & & \\
\hline
\end{tabular}

備考

（1）正常運転時攪拌機（ピット内攪拌）を停止して測定。

(2) フィード濃度は、カローコンに給鉱される濃度。

(3) ピット濃度は、カローコンで濃縮されてピットに入れたもの。

(4) ピット内水位 $0.5 \mathrm{~m}$ 下るまで測定。

(5) ピット容積 $4.0 \mathrm{~m} \times 1.55 \mathrm{~m} \times 0.5 \mathrm{~m}=3,100 l$

（6）揚水量の測定は、ピット内水位の下がる時間から算出したもので あるため正確ではない。従つて上記容積効率む正確なむのでなく 正確な值としては、工場試験成績表に示す88～89\%となる。

\section{6. 現場試験により生じた 問題点とその対策}

(1) サクション抵抗が大きい場合 の対策

往復動ポンプはサクション抵抗が 大きい場合には、ある程度、回転数 を少なくしないとサクションパイプ 内の流体の粘性や摩擦抵抗のため に、ピストンの運動性と流体の運動 性とがマッチしないので、シリンダ 一内で具空が佊れて、ハンチング現 象を惹起するあのであるが、このポ ンプの場合オイルチャンバーがつい ているために、普通の往復動ポンプ よりも大きなイナーシャ一がサクシ ヨン侧に生じ、この現象が特に顕徴 に現われる。（生野鉱業所試験の通 b)

この解決策は回転数を一定に求さ える事亡、サクションパイプにエヤ 一チャンバーを取付ける事によつて 解決された。

回転数はサクションパイブの長さ や構造により、一概に決定はできな いが、 $50 \mathrm{r} / \mathrm{m}$ 以下であれば全然問題

リンダーとオイルチャンバーの連結パイプを大きく改造 し、N鉱山のご好意により約 3 週間連続運転試験を行な うことができた。

その結果は第 4 表及び第 5 図に1例を示す。

この結果、才イルチャンバーに空気が入らない様にす る事と、チャンバーの空気を運転中に簡単に抜く事ので きる構造とすれば、充分実用可能であり、特に、シリン ダーライナー4本/月の消耗だけでも約 10 万円/月の合理 化ができるとの好評を戴いた。

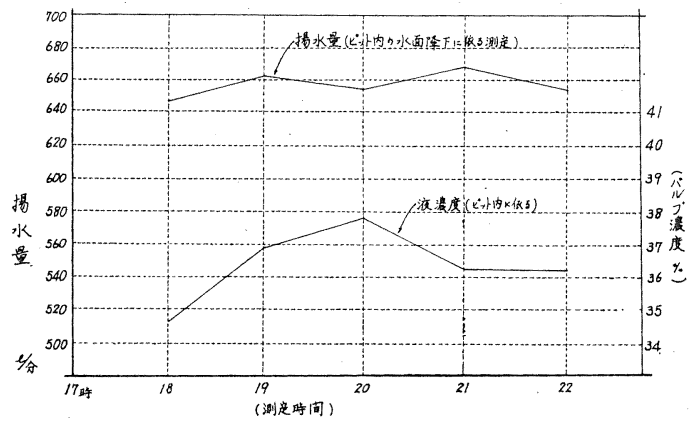

第5図 新型スライムポンプ揚水量及び液濃度 (昭和 37 年10月 3 日調查)
なく、エヤーチャンバーその他サクションパイブの構造 を考虑す机ば、 $55 \mathrm{r} / \mathrm{m}$ までは可能である。

回転数 $50 \mathrm{r} / \mathrm{m}$ 以上の場合のサクション 抵抗の限度の 実験值はサクションパイプの構造にあよるが、大体 250 $m / m \mathrm{Hg}$ までは可能である。

(2) オイルチャンバーに空気が溜る事による容積効率 の低下とその対策

このポンプには、サクション側にオイルチャンバーが あるために運転開始時にシリンダーを含めたサクション 側の中の空気を、完全に除去しないとこの空気がオイル チャンバーの上部に溜り、エヤークッションとなつて著 しくポンプの容積効率を低下させる。

一応の計算では、 $\frac{\text { 吐出圧力 }}{\text { 吸入庄力 }}=400$ 場合チャンバー内 の空気が、ピストン吐出容量の $0.5 \%$ 溜ると容積効率は 正常の場合を $100 \%$ とすると、90\%となり、空気量が 1 \%になると、80\%に容積効率が低下する事になる。

従つて、始動時の空気を完全に抜く事と、運転中オイ ルチャンバーに空気が入らない構造にする事と、オイル チャンバーに入つた空気を運転中、簡単に抜く事が必要 である。、

選鉱工場のスライムには、大なり小なり必ず多くの気 
泡が存在するので、サクションパイブからはこの気泡が 吸入されるのを防ぐ事はできないので、吸入された空気 がオイルチャンバーまで入らない様にする事が必要であ る。

そのためには、第 1 図の様にバルブボックスとオイル チャンバーとの間の連結管を逆サイフォン型とした。 には空気が充満しているので、てのサクションパイブに 水が充満するまでの間は、空気を吸入する事になるの で、この空気がオイルチャンバーに入つて来ない様にす る必要がある。

そのためには連結管の容量を大きくして、シリンダー の1ストロークの容量だけの空気を吸入してもての空気 がオイルチャンバーの下部まで絶対侵入しない様にした 事で解決された。（尾去沢に括ける試験結果之、後述 2 号機による工場試験で立証される)

また、始動時完全に抜けなかつた空気が、オイルチャ ンバーに溜つた場合は、運転中簡単にこの空気を抜く事 ができる様に、特殊バルブを取付ける事によつて解決さ 机た。

（3）運転中オイルチャンバー内の油量の確認と調整が できるかどうか。

前述の通りオイルチャンバー内の空気は始動時に充分 除去しても、なかなか、完全には除去できないもので、 てれは運転開始してから徐々に、オイルチャンバーの上 部に溜つて来ると容積効率の低下を生ずるので、どうし ても運転中にての空気を除く必要があり、前述の様なバ ルブを取付壮る事によつて解決されたが、この場合、若 干の油が空気と一緒に補助タンクに放出されるので、回
また、始動時には、バルブから先のサクションパイプ

を重ねるとオイルチャンバー内の油量が減少する事にな る。

この場合の油量の確認は補助タンクに第 6 図の様に、 ゲージグラスを取付ける事によつて確認される。

また、その減少した油をオイルチャンバーに補給する ために、特殊バルブを取付ける事によつて運転中簡単に 油の補給が可能となつた。

(4) 休転時の対策

休転時連結管内のスライムが沈降し、再起動に支障を 来たす恐れがあつたが、その対策は連結管内のサンドが 全部底面に沈測しても管断面が 100\% 閉鎖されない様 に、連結管の容積を設訃する事によつて解決された。

しかし、寒冷地では凍結のために、どうしても連結管 のスライムを拔き出さなけ机ばならないが、この場合 は、第 1 図及び第6 図の給水パイプより圧力水 ( $2 \mathrm{~kg} /$ $\mathrm{cm}^{2}$ 位) を注入し、オイルチャンバー上部の油補給弁を 開く事により、簡単にオイルチャンバー内の油を補助夕 ンクに抜出す事ができるので、その後第 1 図及び第 6 図 の排水弁を開けば簡単に連結管内のスライムは除去でき る。

\section{7. 試作 2 号機について・}

1 号機による前述の諸実験の結果、確認された種々の 問題点を勘案して、2 号機を製作し、工場試験を行な い、大体満足すべき結果を得る事ができたので、その概 要を説明する。

(1) 仕 様

$$
\begin{array}{ll}
\text { シリンダー径 } & 185 \mathrm{~m} / \mathrm{m} \times 2 \text { 本 } \\
\text { ストローク } & 350 \mathrm{~m} / \mathrm{m}
\end{array}
$$

回転 数 48.5 (試験は 44 $\mathrm{r} / \mathrm{m}$ 及び $51 \mathrm{r} / \mathrm{m}$ で施行）

吐出圧力最大 $40 \mathrm{~kg} / \mathrm{cm}^{2}$ 吐 出 量 $1.5 \mathrm{~m}^{3} / \mathrm{min}$ 使用電動機 $200 \mathrm{PP}$

\section{(2) 構造概要}

(1)(1) (1)

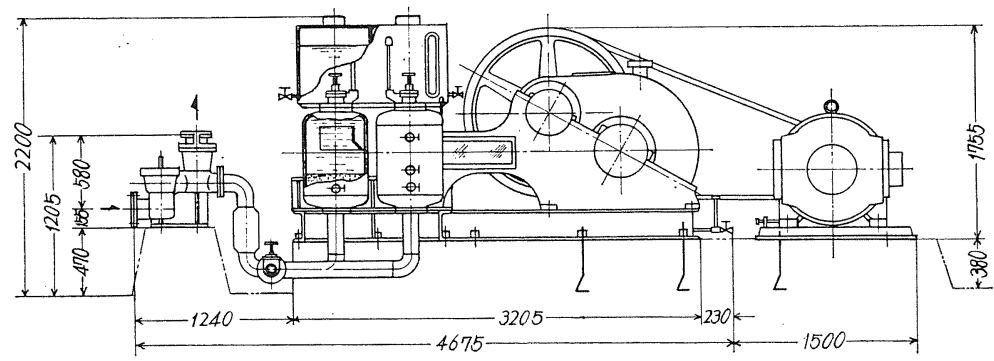

第6 図 $180 \phi \times 350$ 型低圧新型スライムポンプ
第 6 図の様に 4 つのオイルチ ヤンバーの真中上部に油補給タ ンクを設け、とのタンクの内部 は4つに区分さ机、各々 4 つの オイルチャンバー上部の空気抜 弁及び、油補給弁と透明ビニー ルパイプで連結され、パイブ中 を流机る気泡や油が確認できる 栐になつている。

また、補助タンクの油面の変 化は、外部より見える様にゲー 


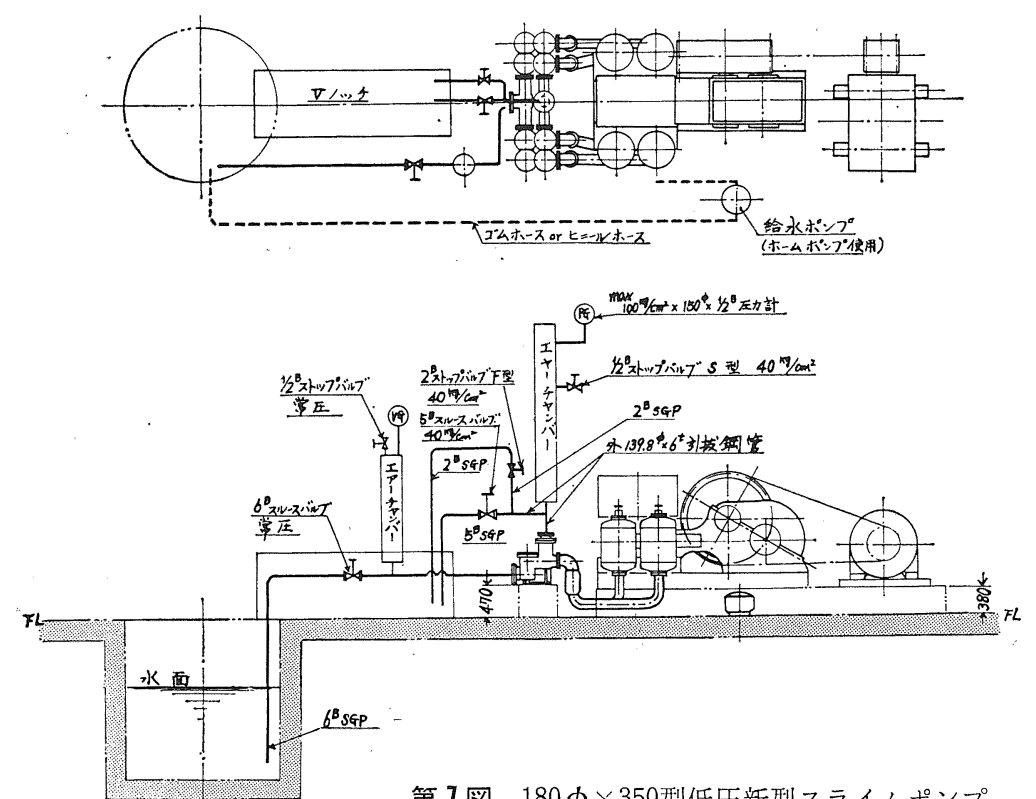

第 7 図 $180 \phi \times 350$ 型低圧新型スライムポンプ

即ち、

(1) サクションパイプにエヤ ーチャンバーを設けた。

(ロ) オイルチャンバーとバル ブボックスの連結管の構造 容積を合理的に設計した。

(け) 運転中オイルチャンバー 内の空気を簡単に抜く事が でき、また、補助タンクか ら運転中簡単に油をオイル チャンバーに補給できる様 に特殊弁を取付けた。

(二) 補給タンクの油面計を見 る事によつて、オイルチャ ンバー内の油面を充分管理 できる様にした。

等である。

（3）工場試験結果について

(1) 配 置

第7図に示す。

第 5 表 ポンプ試験表

仕様（土号）1252 (機番) D.L.P 108 (型式) 横型複筒復動 (試験施行) 昭和 38 年 4 月 17 日 (シリンダー径) $185 \mathrm{~m} / \mathrm{m}$ 中 （シリンダー数）2 (行程) $350 \mathrm{~m} / \mathrm{m}$ (回転数) $40.5 \mathrm{R} / \mathrm{M}$ (全印力) ${ }_{40}^{22} \mathrm{~kg} / \mathrm{cm}^{2}$ （揚液量） ${ }_{1500}^{1250} \mathrm{l} / \mathrm{m}$

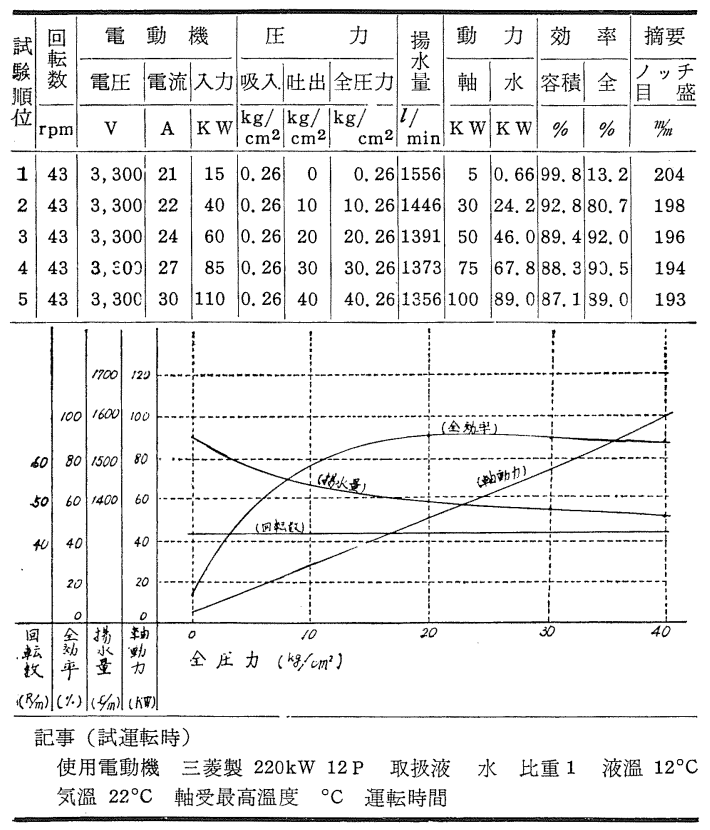

ジグラスを取付けている。

その他、前述の(1) (4)の問題点を全部解決した構造と なつている。
(口) 試 験

回転数 $43 \mathrm{r} / \mathrm{m}$ 及び $51 \mathrm{r} / \mathrm{m}$ の 2 様について行ない、 サクションパイプより空気を吸入させる試験及び、オ イルチャンバーに一定量の空気を入れた場合の容積効 率の低下の測定を行なつた。

(⿻) 試験結果

第 5 表及び第 6 表の通りであり、

(a) 最高圧力 $40 \mathrm{~kg} / \mathrm{cm}^{2}$ の場合の容積効率は、 $43 \mathrm{r} / \mathrm{m}$ で $87.1 \% 、 51 \mathrm{r} / \mathrm{m}$ で $88.6 \%$ であつた。

(b) 長時間運転による容積効率の変化は第 7 表の通 り、8 時間運転で全く変化なく空気の混入はない ものと判断された。

(c) サクションパイプを取付けたコックより 3 分間 空気を吸わせ、次にコックを閉じて空気の吸入を 止める実験を 2 回絽返えし行なつた結果は下表の 通りである。

\begin{tabular}{|c|c|c|c|c|}
\hline & 回転数 & 吐出圧力 & 吸入圧 & 吐出量 \\
\hline $\begin{array}{l}\text { 空気吸入しない } \\
\text { 時 }\end{array}$ & $43^{\mathrm{R} / \mathrm{M}}$ & $\begin{array}{l}\mathrm{kg} / \mathrm{cm}^{2} \\
30 \\
\end{array}$ & $\begin{array}{l}\mathrm{mmHg} \\
180\end{array}$ & $\begin{array}{l}l / \min \\
1,373\end{array}$ \\
\hline 空気吸入中 & 43 & 30 & 165 & 1,270 \\
\hline $\begin{array}{l}\text { 空気吸入中止し } \\
\text { た時 }\end{array}$ & 43 & 30 & 180 & 1,373 \\
\hline 再び空気吸入中 & 43 & 30 & 165 & 1,237 \\
\hline 空気吸入中止 & 43 & 30 & 180 & 1,373 \\
\hline
\end{tabular}

即ち、サクションパイプより空気を吸入しても オイルチャンバーに空気は侵入しない事が確認さ 
第 6 表 ポンプ試験表

仕様 （工号）1252 (機番) D.L.P 108 (型式) 横型複筒復動 (試験施行) 昭和 38 年 4 月18日

（シリンター径）185 ${ }^{\prime \prime \prime} \phi$ （ンリンダー数） 2

（行程） 350 m $/$ (回転数) $40.5 \mathrm{R} / \mathrm{M}$

(全正力) ${ }_{40}^{22} \mathrm{~kg} / \mathrm{cm}^{2}$ (揚液量) ${ }_{1550}^{1250} \mathrm{l} / \mathrm{min}$

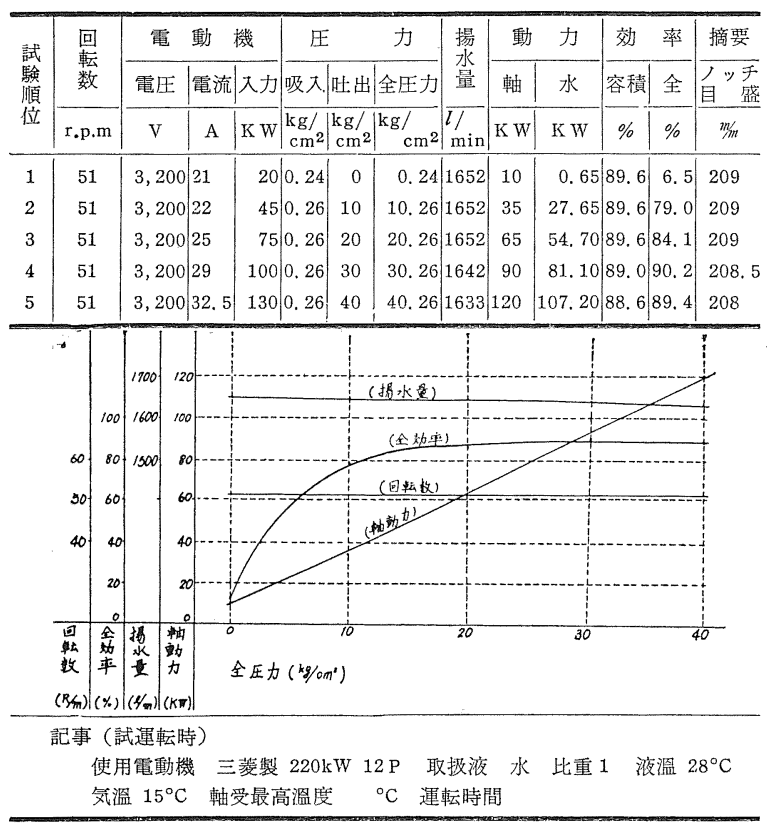

れた。

(d) オイルチャンバーに、一定量の空気老入れた場 合の容積効率の変化を確認するために、1本の才 イルチャンバーに、その容量の $0.5 \%$ 空気を入 れた場合之、2本のオイルチャンバーに同じく $0.5 \%$ の空気を入れた場合の試験を行ない、その 結果は次表の通りである。

計算ではこの場合容積効率は $82.3 \%$ あり、大 体計算通りの結果が確認された。

(e) オイルチャンバー内の油量の変化について前述 の 8 時間連続運転後ポンプを休止し、油面検出コ

第 7 表 $180 \phi \times 350$ 型 新型スライムポンプ試験表

\begin{tabular}{l|c|c|c|c|c}
\hline & 回転数 四入圧 & 吐出圧 & 吐出量 & 容積 \\
\hline 交
\end{tabular}

ックを開いた結果、直ちに油が流出した。

即ち、油量は全く減少していない事が確認 され、この事は絶対に油が水に混入して流出 していない事の確認として最も重要な事であ る。

(£) サクション抵抗の最大限の確認 前述の様にサクション抵抗は、その配管方 式によつて異なるので、このポンプの最大可 能サクション抵抗值の決定は、今後検討して 決定する積りであるが、その 1 例として第7 図の配置の場合 $51 \mathrm{r} / \mathrm{m}$ で運転した場合の最 大可能抵抗を確認するためにサクションパイ プに取付けたバルブにより抵抗を増加しなが ら、ハンチングの発生する状態を調査した結 果、 $250 \mathrm{~m} / \mathrm{mg}$ 、即ち、約 $0.33 \mathrm{~kg} / \mathrm{cm}^{2}$ までは 全然ハンチングが発生しない事を確認した。 勿論配管を改良すれば更に高抵抗です使用可能で ある。

\section{8. 結}

論

以上試作 2 号機までの設計と試験結果の大要を述べた が、この結果、充分実用可能であり、しかす従来眯案之 なつているシリンダーライナー、ピストン、ピストンロ ッド、グランドパッキング等の摩耗は殆んどなくなるの で、在来のスライムポンプと比較した場合、第1表に例 をとれば(1) (12)までの合計金額 348,000円/5 ケ月（835

\begin{tabular}{c|c|c|c|c|c|c|c|c|c|c}
\hline $\begin{array}{c}\text { 時 間 } \\
\mathrm{H}\end{array}$ & $\begin{array}{c}\text { 回転数 } \\
\mathrm{R} / \mathrm{M}\end{array}$ & $\begin{array}{c}\text { 電 } \\
\mathrm{V}\end{array}$ & $\begin{array}{c}\text { 電 流 } \\
\mathrm{A}\end{array}$ & $\begin{array}{c}\text { 入 力 } \\
\mathrm{kW}\end{array}$ & $\begin{array}{c}\text { 軸動力 } \\
\mathrm{kW}\end{array}$ & $\begin{array}{c}\text { 吐出量 } \\
\mathrm{L} / \mathrm{M}\end{array}$ & $\begin{array}{c}\text { 全効率 } \\
\%\end{array}$ & $\begin{array}{c}\text { 容積効率 } \\
\%\end{array}$ & $\begin{array}{c}\text { 電素動機 } \\
\text { 温度 }\end{array}$ & $\begin{array}{c}\text { 大気温度 } \\
{ }^{\circ} \mathrm{C}\end{array}$ \\
\hline 11.00 & 43 & 3,300 & 27.0 & 85 & 75 & 1,373 & 90.5 & 88.3 & - & - \\
14.00 & 43 & 3,215 & 27.0 & 83 & 73 & 1,373 & - & - & 48.0 & 26 \\
15.00 & 43 & 3,355 & 27.0 & 83 & 73 & 1,373 & - & - & 49.0 & 26 \\
16.00 & 43 & 3,480 & 30.5 & 85 & 75 & 1,373 & - & - & 49.5 & 26 \\
17.00 & 43 & 3,450 & 29.5 & 83 & 73 & 1,373 & - & - & 49.0 & 22 \\
18.00 & 43 & 3,400 & 28.0 & 83 & 73 & 1,373 & - & - & 49.0 & 19 \\
19.00 & 43 & 3,400 & 28.0 & 83 & 73 & 1,373 & - & - & 47.0 & 18 \\
\hline
\end{tabular}

仕様 (工号) 1252

(機番) D. L. P 108

吐出圧力 $30 \mathrm{~kg} / \mathrm{cm}^{2}$ 時に打ける連続運転経過記録 
千円/年）は少なくとも物品費の節約となる。（71/4” X $14^{\prime \prime}$ の大型ポンプの場合約 1,350,000円/年)

こ机は物品費のみであり、これの取替えに要する労務 費の節約を考えると、大きな合理化になると確信する次 第である。

また、在来のスライムポンプはこの消耗部品取替えの ため、常に 1 台の予備機を設置しなければ操業不能であ るが、とのポンプの場合はバルブ関係のみの取替えで単
時間に交換できるので、24時間連続運転でなければ、予 備機の必要はなく、また、24時間連続運転の場合につい て屯、本体は全々交換部品の必要がないので、バルブボ ックスのみを 2 組設置し、連結管の切替バルブの操作を 行なう事によつて1台のポンプのみで、操業可能にする 事を研究中である。

な拉、との新型スライムポンプの構造については、既 に特許認可を得ている事を附記して説明を終る。

\section{$\overline{\text { 見学記-6 }}$ 同 和 鉱 業 (株) 岡 山製 錬 所}

例会終了後、見学班一行は、岡山市飞宿泊乙翌16日朝 製鍊所飞到着した。吉田所長の御挨拶の後、鳥居課長か ら岡山製鍊所の概沉について詳細なるご説明を择聴した 後、長時間にわたり懇切なるご案内を受けながら所内を 見学させていただいた。以下その概要を紹介すると次の 通りである。

位置

同和鉣業侏岡山製錬所は、国鉄岡山駅南方約 $10 \mathrm{~km}$ 、 岡山市南部工業地带飞位置し、南は児島湾、東は旭川河 ロに面している。

\section{沿革}

昭和 26 年 6 月同和鉱業(侏)、神島化学工業(侏)、藤田興業 侏、鐘淵紡績侏の 4 社が、硫酸製造を目的として西日本 化学工業株式会社を設立し、硫酸工場の建設飞着手し た。同和鈗業侏が昭和 27 年 12 月硫酸焼鉱の脱収銅設備の

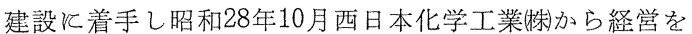
委託され同和鉱業(侏岡山製錬所として発足した。昭和 31 年 7 月設備を增強し、昭和 35 年 10 月銅製鍊設備を新設し 昭和 36 年 9 月硫酸製造設備を增強乙昭和 37 年 2 月銅電解 設備を增強し今日にいたつている。

製造系統以硫酸化焙焼系統と銅製錬系統とに分けられ る。

\section{硫酸化焙焼系統}

同和鉱業(侏)棚原鉱業所産磁硫鉄鉱物よび硫化鉱を主体 として処理している。

\section{貯鉱および調合}

貨車をカーダンパ飞より傾転し鉣石はスタッカーを絽 て貯鉱場にベッディングされた後、グラブクレーンにて 払出されコーンクラッシャーを経てー $10 \mathrm{~mm}$ となり貯鉱 舎飞送られる。

\section{粉砕および摈焼}

ボール・ミルとエーキンス分級機で閉回路粉㻊し、そ の分級機オーバーフローをアシテーター付コーンタンク で濃縮し、そのスピゴットをフリュオンリッド焙焼灯炕 給鉱する。コーン・タンクのオーパーフローはボール・ ミルル繰返される。焙焼炉内で焙焼温度 $650^{\circ} \mathrm{C} て ゙$ 硫酸化 焙焼する。焙焼炉オーバーフロー中の焼鉱は、その大部 分がサイクロンで回収され続いて残部がコットレル収塵 装置などで回収される。焼鉱はいずれも薄硫酸の浸出液 でパルプとなり脱銅工程に入る。焙焼炬排ガスはサイク ロン、コットレル収蝔装置を経て硫酸系統と入る。

\section{脱銅および収銅}

パルプとなつた焼鉱は、リーチング・タンク内で靦拌 抽出され、まず第 1 ドラッグ・ベルトで粗粒鉱と微粒鉱 飞分離される。粗粒鉱第 $2 、$ 第 3 ドラッグ・ベルトで 洗临脱水され、さら飞フィルターで脱水される。微粉鉱 は第 1 シックナーに入り、このオーバーフローは焙焼炉 クェンチタンクに繰返され、スピゴットは第 2、第 $3 、$ 第 4 シックナーでカウンター・カレント方式で洗涤さ れ、第 2 ンックナーのオーバーフローが銅液として収銅 槽飞送られる。スピゴットは、第 4 シックナーで洗滌が 終り、ドラッグ・ベルトからの粗粒鉱と共に、フィル夕 一で脱水され脱銅焼鉱（Fe 57〜 58\% Cu 0.15\%）とな り製鉄原料と乙て出荷される。銅液は送風収銅槽で鉄屑 を使用して可溶性銅を沈澱銅として回収され、尾液は脱 銅工程の洗滌液拈よびコットレル煙灰の抽出液として繰 返し使用される。

\section{硫酸製造}

サイクロン、コットル収塵装置を通過した焙焼炉排ガ スは、増湿塔、冷却塔、洗滌塔、ミスト・コットレル、 乾燥塔、排風機、熱交換器を経て転化器飞入り、 $\mathrm{SO}_{2}$ が $\mathrm{SO}_{3}$ となり、吸収塔で $\mathrm{H}_{2} \mathrm{SO}_{4}$ となる。硫酸化焙焼の冷 却水を多量飞使用するため薄硫酸が生ずるので、これの 大部分が脱銅工程に使用される。

\section{銅 製 䡛 系 統}

銅鉱をフリユオソリッド焙焼炉で酸化焙焼した㳳鉱に コークスを還元剤として混合し電気炉で熔融反応させ粗 銅を作り、これを精製炬で不純物を除去して粗銅板と し、これを電気分解して電気銅とする。電気炉鍰な、尼 崎選鉱場で硫酸化焙焼後脱銅されて製鉄原料となる。酸 化焙焼時の発生ガスは、余熱回収後硫酸系統飞入る。回 収余熱は銅電解液加温飞使用される。

\section{公害 処 理}

硫酸工場排出ガス中の少量の未反応亜硫酸ガスを除害 塔で炭酸ソーダに吸収して佂硫酸ソーダを製造する。

月間の生産能力は、電気銅 $800 \mathrm{t}$ 、脱銅焼鉄鉱 $6,100 \mathrm{t}$ 濃硫酸 $10,000 \mathrm{t}$ 、西硫酸シータ $200 \mathrm{t}$ で、従業員数は227 名である。

斬新なアイディアを勇敢に実行している岡山製錬所の 将来の発展を祈りつつ一行は車の人となつた。

参加者：光富勝義（東邦悪鉛）、高木孟義（日本鉱業 協会）、藤本浩三（日本鉱業）、加島二郎（事務局）。 （日鉣・中研・藤本記） 